\title{
Is It Chilly Out There? International Investment Agreements and Government Regulatory Autonomy
}

\author{
Christine Côté, London School of Economics and Political Science, UK
}

CONCERNS THAT INTERNATIONAL INVESTMENT agreements (IIAs) impact a government's right to regulate and lead to "regulatory chill" have once again surfaced in the wake of the negotiations on the Pacific Rim's Transpacific Partnership (TTP) and the US-EU Transatlantic Trade and Investment Partnership (TTIP). These concerns are not new and have persisted since NAFTA Chapter 11 on investment highlighted the threat of private access to international arbitration through investor state dispute settlement provisions (ISDS) and led to unprecedented challenges to government regulations, particularly in the area of health, safety, and the environment (HSE). Are these concerns valid, and to what extent do such trade and investment agreements impact the regulatory development process and lead to regulatory chill? In this essay, I briefly introduce some insight from my on research based on interviews with HSE regulators in Canada, before reflecting on the broader implications for international trade and investment policy and domestic regulatory development in other countries.

\section{How Much Do Regulators Actually Know?}

In my own research (Côté, 2014), I have investigated the impact of international investment agreements, particularly NAFTA Chapter 11 on the Canadian regulatory development process, through in-depth interviews and an extensive survey of Canadian regulators. Canada provided a perfect case for testing the theory of regulatory chill, given the high number of legal challenges the country has faced to its HSE regulations. By talking to Canadian HSE regulators, I sought to determine their level of awareness of international investment agreements and the potential for legal challenge by private actors as well as the extent to which they took these investment commitments into account when developing regulations. The empirical analysis revealed that Canadian regulators were not focused on avoiding investment disputes when developing regulation. Regulators were instead more interested in complying with international standards and commitments and harmonizing regulations with the US and internationally. They were focused on responding to health, safety, and environmental needs, to advances in science and technology, and to the expectations of stakeholders. Furthermore, while Canadian regulators sought to ensure that their regulations did not act as barriers to the flow of international trade, they did so while responding to recent domestic streamlining and modernization initiatives.

The strongest predictor of a regulator's likelihood to consider trade and investment dispute avoidance as a factor was with respect to the WTO, where investment disputes do not lead to direct challenges and litigation from private actors. Interestingly, regulators were generally not able to differentiate between the different types of trade fora or agreements or their implications. Most references to trade and investment commitments referred to Sanitary and Phytosanitary (SPS) or Technical Barriers to Trade (TBT) commitments under the WTO or NAFTA, while NAFTA Chapter 11 did not rank high as an influencing factor. Where there had been a NAFTA Chapter 11 dispute that had impacted one of their regulatory measures, the level of knowledge was still quite vague and the understanding of the implications or costs associated with such a challenge was not high. Only $12 \%$ of regulators were aware of any such threats of investment disputes, and among those regulators that were aware of NAFTA Chapter 11 disputes, 42\% claimed that despite this awareness it did not in any way influence the regulatory development process.

At the same time, a statistical analysis of HSE regulatory changes in the study between 1998 and 2013 showed an increasing trend in the stringency and comprehensiveness of regulations in health safety and environment. Senior Federal HSE regulators in Canada confirmed the point that regulations in HSE have generally been increasing in stringency and comprehensiveness driven by new areas now being regulated, deeper science requirements, a strong international influence, increasing public scrutiny and demands, and the push for harmonization of regulations with the US.

My research found little consistent evidence of either downward trends in stringency and comprehensiveness of HSE regulations on the back of NAFTA investment disputes, or evidence that regulators took a threat of an investment dispute into consideration when developing regulations. Furthermore, my study also highlighted a number of other trends in regulatory development which inform the debate on the impact of globalization and concerns about regulatory chill.

\section{Regulation: Racing to the Bottom, or to the Top?}

Just as globalization scholars have considered whether competitive pressure and the threat of exit by mobile firms and capital have had constraining influences on national policies, there is a view that the threat of litigation through rights provided to private actors by IIAs will constrain the regulatory ability of the state, leading to regulatory chill. My research has found weak empirical support for the hypothesis on 
regulatory chill in the case of Canada, suggesting that international investment agreements, as one component of globalization, may not be restricting national regulatory autonomy in the area of health, safety, and the environment as is feared. This result suggests policy divergence whereby globalization in the form of IIAs has not prevented different approaches to national policies, hindered national policy autonomy, or resulted in a decline in social welfare policies.

To the contrary, my study provides evidence for an upward convergence in regulation, or a "race-to-the-top" (Drezner, 2001) driven by ideational forces or policy diffu-

sion, rather than a "race

to the bottom" driven

by competition for capital or investment (Spar, 1998). This policy diffusion or emulation is "characterized by the voluntary adoption of

policies put forward by experts and international organizations, rather than their adoption through coercion" (Simmon, Dobbin, \& Garret, 2008).

This trend was evidenced first by the focus on harmonization as outlined in the Canada-US context across many key regulatory areas. Regulators placed harmonization with the US high on the list of influencing factors, and the statistical analysis of HSE regulations revealed a series of regulatory increases in areas such as transport safety and the reduction of vehicle emissions to reduce greenhouse gases which were overwhelmingly motivated by a desire to align with higher US standards. Regulators also highlighted the influential nature of the work of international standard setting bodies such as the WHO organization on international food standards (CODEX) and the Intergovernmental Panel on Climate Control (IPCC). These bodies set high level standards on food safety and emissions, which countries such as Canada seek to emulate.

The overall evidence thus points to a shift towards better regulation rather than less regulation. This reflects the concept of re-regulation in which governments "reorganized their control of private sector behaviour, but do not substantially reduced the level of regulation" (Vogel, 1996) and the absence of a zero sum trade-off between governments and markets. This new approach to regulating was very much in evidence in the case of Canada, where regulators consistently claimed that efforts at modernization, efficiency improvement, and streamlining of regulations were not done at the expense of regulatory stringency or comprehensiveness but continued to be driven by the core goals of meeting health, safety, and environmental sustainability needs. The manifestation of this approach was a shift from process to output based regulations, a greater cost/benefit focus, the use of alternative control mechanisms, as well as the movement to smarter focused regulations. Initiatives such as the 2007 Cabinet Directive on Streamlining Regulations and the 2012 Red Tape Reduction Plan in Canada are examples of this point.

\section{Regulatory Chill in a Broader Trade and Invest- ment Context}

If interviewees in my study considered the impact of trade and investment at all, they focused almost exclusively on the WTO or on TBT and SPS commitments in other trade agreements. This is not surprising given the involvement that health, safety, and environmental regulators are likely to have with TBT and SPS issues within the WTO and within NAFTA in the case of Canada. The high profile nature of WTO disputes and potential impact on the policies of member states is also most certainly a defining factor. Past cases at the WTO have been high profile and resulted in tribunal rulings on the trade compatibility of HSE measures, providing pressure for countries to undertake amendments to ensure compliance. The US-EU Beef Hormones Dispute regarding "Measures Concerning Meat and Meat Products (Hormones),"1 the Mexico-US Tuna Dolphin Dispute regarding "Measures Concerning the Importation, Marketing and Sale of Tuna and Tuna Products,"2 and the US-Indonesia Cigarette Clove Dispute regarding "Measures Affecting the Production and Sale of Clove Cigarettes" ${ }^{\prime \prime}$ all serve to highlight the stakes for developed and developing countries in this forum on HSE regulatory issues.

It is certainly conceivable that the possibility of challenges within this forum as well as an actual dispute such as the one launched by numerous countries against Australia's plain packaging legislation is having a chilling impact. The survey results certainly suggest that countries take this into account more than any other trade and investment factor. What is the implication of this for our question of regulatory chill? One key difference is that these WTO disputes are driven and championed by other countries rather than private actors (although the spectre of industry influence is large in many cases). This would in general suggest that the debate on regulatory chill needs to be recast with respect to the arguments put forward by public policy advocates, NGOs, and the general public. Those scholars who have looked at the issue of the impact of IIAs have tended to take a narrow focus on one fora or another but rarely across all to consider the broader impact. The results of my study suggest that scholars might be well placed to broaden the scope of their focus to encompass the influence of this larger set of trade and investment issues. It was clear from discussions with regulators that they did not often differentiate between fora, or tended to consider the impact of disputes across all fora (WTO, domestic litigation, FTA) as one set of factors on trade and investment that could have an impact on the regulatory development process. 


\section{Challenges for Developing Countries}

A key differentiating factor between developed and developing countries is the relative strength of domestic institutions and their ability to support regulatory choices. As Rodrik (2007: 195) has argued, "globalization benefits countries with strong existing institutions while hindering the ability of nations to build institutions to address both regulatory and redistributive issues."While not relevant to the Canadian study, the reality is that less developed countries engaged in international trade and investment are often struggling to put in place the most basic levels of regulatory policy, and are often consumed with ensuring that their existing regulations are actually being implemented. They are more vulnerable to intimidation by industry groups (such as in the case of the tobacco industry), which can serve to hinder the establishment of strong policies.

Another differentiator for developing countries is the potentially greater relative financial burden they face with respect to investment challenges and the deterring impact this is likely to have on their desire to pursue policies that could result in a dispute. Concerns in general about the cost of arbitration are driven by both the size of the awards and the costs of defending the state. Most recently, in 2012"the highest known award of damages in the history of investment treaty arbitration featured in Occidental v. Ecuador // where the investor was awarded US\$1.77 billion plus pre and post award interest" (UNCTAD, 2013: 19). ${ }^{4}$ This is not a new trend and has been an issue of some concern for a number of years. On average the cost of an arbitration case is upwards of US\$8 million per party, with legal fees making up $82 \%$ of this cost (Graukrogder \& Gordon, 2012).

Finally, many developing countries face challenges from the lack of available domestic trade and investment expertise. Gottwald (2007: 252) identifies what he sees as the top three barriers for developing nations' participation in the international investment arbitration process: "a lack of affordable access to legal expertise, a lack of transparency in the arbitration process, and uncertainty over the meaning of key treaty rights." This hinders their ability to negotiate treaties that reflect their interests (through appropriate carve-outs for regulatory policy space) as well as their ability to defend themselves should an ISDS dispute arise. Moreover this absence of trade and investment experience and expertise is also felt amongst HSE regulators and accounts for the low level of awareness of these threats and their implications. Coupled with the financial constraints raised above, the overall possibility that a threat of an ISDS challenge could lead to a chilling of regulation in a developing country seems more plausible. Ultimately, however, if Canadian HSE regulators are unaware of the regulatory implications of international trade and investment treaties, despite the high level of ISDS challenges they have faced, how likely is it that regulators in developing countries are making informed decisions when signing international treaties, and implementing domestic regulation?

\section{References}

Côté, C. 2014. A chilling effect? The impact of international investment agreements on national regulatory autonomy in the areas of health, safety and the environment. PhD Thesis, London School of Economics. http://etheses.lse.ac.uk/897/

Drezner, D. W. 2001. "Globalization and Policy Convergence." International Studies Review, 3: 75-76.

Gaukrodger, D., \& Gordon. K. 2012. Investor-state dispute settlement: A scoping paper for the investment policy community. OECD Working Papers on International Investment, No 2012/3, OECD Investment Division.

Gottwald, E. 2007. Levelling the Playing Field: Is It Time for a Legal Assistance Center for Developing Nations in Investment Treaty Arbitration? American University International Law Review. 22: 237.

Rodrik, D. 2007. One Economics Many Recipes: Globalization, Institutions and Economic Growth. Princeton, NJ: Princeton University Press.

Simmons, B. A., Dobbin, F., \& Garrett, G. 2008. The Global Diffusion of Markets and Democracy. Cambridge: Cambridge University Press.

Spar, D. 1999. The spotlight and the bottom line. Foreign Affairs, 77(2): 7-12.

UNCTAD. 2013. Recent Developments in Investor-State Dispute Settlement (ISDS). Geneva: UNCTAD.

Vogel, S. 1996. Freer Markets, More Rules: Regulatory Reform in Advanced Industrial Countries. Cornell University Press.

\section{Endnotes}

1 http://www.wto.org/english/tratop_e/dispu_e/cases_e/ds26_e.htm

2 http://www.wto.org/english/tratop_e/dispu_e/cases_e/ds381_e.htm

3 http://www.wto.org/english/tratop_e/dispu_e/cases_e/ds406_e.htm

4 Other cases of note were EDF v. Argentina with an award of $\$ 13.73$ million, Deutsche Bank v. Sri Lanka with an award of $\$ 60.36$ million and SGS v. Paraguay with an award of $\$ 39.02$ million.

Christine Côté (C.Cote@lse.ac.uk) is a Visiting Fellow at the London School of Economics and Political Science where she received her $\mathrm{PhD}$ in International Political Economy and teaches on foreign direct investment and public management and governance. Prior to entering academia she worked as an international trade negotiator with the Department of Foreign Affairs and International Trade Canada, representing Canada in negotiations at the WTO, the OECD and on bilateral trade and investment agreements. 